\title{
缶溶出スズ投与ラットの骨強度変化について
}

(昭和 59 年 2 月 15 日受理)

\author{
石見恵子*1 御興久美子*1 \\ 森山忠重 ${ }^{* 1}$ 南斎征夫*2
}

\section{Effect of Corrosion Tin from Canned Juice on the Mechanical Strength of Rat Bone}

\author{
Keiko IwAmI*1, Kumiko OgoshI*1, Tadashige MoRIYAMA*1 \\ and Yukuo NANZAI*2 \\ (*1 Department of Public Health, Nara Medical University: \\ 840 Shijo-cho, Kashihara, Nara, Japan; \\ *2 Faculty of Engineering, Osaka City University: 3-3-138 Sugimoto, \\ Sumiyoshi-ku, Osaka, Japan)
}

\begin{abstract}
The toxic effects of corrosion tin from canned juice on the bone and blood of rats were examined. Wistar male rats were divided into three groups and treated with 0,230 or 454 $\mathrm{ppm}$ of corrosion tin in the drinking water for four weeks. After the treatment all the rats were killed by bleeding and the femurs, humeri and tibiae were dissected out. The bones were cleaned of soft tissues and subjected to compression and bending tests.

The following results were obtained.

1) In the $454 \mathrm{ppm}$ group, the compressive strength of the distal end of the femur and the proximal end of the humerus were significantly decreased. There were no significant changes in the bending strength of the diaphysis of the femur, humerus and tibia.

2) No significant difference was observed in the mechanical strength of bones of the $230 \mathrm{ppm}$ group compared with the control group.

3) Anemia was observed in the $454 \mathrm{ppm}$ group, but not in the $230 \mathrm{ppm}$ group.
\end{abstract}

(Received February 15, 1984)

Key words: 溶出スズ corrosion tin; 缶ジュース canned juice; 骨の強度 mechanical strength of bone; ラット rat; 貧血 anemia

\section{緒訔}

スズは自然界に広く分布し，食物を介してヒトの体内 にとりこまれることの多い重金属の 1 つである. 肉類, 穀類, 野菜などには, 普通約数 ppm のスズが含まれて

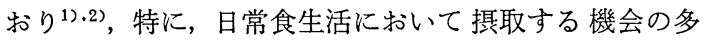
い缶詰食品, 缶詰飲料水中には, 数 $10 \mathrm{ppm}$ から時には 数 $100 \mathrm{ppm}$ のスズが検出されることがある ${ }^{3)}$.

ヒトが多量のスズを含む缶詰食品を摂取すると，嘔 吐・下痢などの一過性の急性胃腸障害を示すことはよく

*1 奈良県立医科大学公衆衛生学教室：奈良県㮒原市 四条町 840

*2 大阪市立大学工学部：大阪市住吉区杉本 3-3-138
知られた事実である ${ }^{4) .5) . ~}$

Schroeder ら ${ }^{11}$ は，ヒトへのスズの蓄積は主として缶 詰食品の摂取に由来し, 缶詰食品摂取量の多いアメリカ 住民は，摂取の少ないアフリカ住民よりもスズの藏器蓄 積量が 6〜8 倍高いことを報告している. 経口的に摂取 されたスズは生体中で骨・リンパ節・肝臓・腎葴に蓄積 されるので6), これらの臟器に何らかの影響を及ぼして いることが考えられる.

著者らはこれまでに, 塩化第一スズ溶液 $50 \mathrm{ppm}$ をラ ットに 3 週間投与した 実験で，骨形成阻害を認め7), ま た， $300 \mathrm{ppm} 4$ 週間投与実験では，大腿骨骨端部の圧 縮強度の低下を認めている ${ }^{8)}$. た, 山ロら ${ }^{9)}$ も塩化第一 
スズ及び缶溶出スズを投与したラットの骨におけるスズ の蓄積とカルシウム量の低下を報告している.

一般に重金属の毒性はその化学形態によって異なるこ とが知られているが，2 価のスズ化合物である缶溶出ス ズ*1 と塩化第一スズは，共に骨中カルシウム量を低下さ せる と) といら点で，骨に対する作用が似ていると考えら れる. 従って缶溶出スズの生体への作用としては一過性 の食中毒症状のみならず，塩化第一スズと同様に骨のカ ルシウム代謝に影響を及ぼし，骨の強さを低下させる可 能性が考えられる，そこで著者らは日常食生活において 実際に摂取する機会の多い缶からの溶出スズの毒性を検 討することを目的として，缶溶出スズをラットに経口投 与して骨の力学的強度に及ぼす影響を調べた.

\section{実 験方法}

\section{1. 缶溶出スズモデルジュース}

本研究で用いた缶溶出スズ原液は， $0.23 \%$ クェン酸 に $15 \mathrm{ppm}$ の硝酸カリウムを加え, 水酸化ナトリウムを 加えて $\mathrm{pH} 3.4$ にした液を, 内面無塗装の 5 号缶に, 熱 間充てん巻締にて封入して約半年間, $37^{\circ}$ 保温室に放置 し，スズを液中に溶出させたものであり，東洋食品研究 所堀尾嘉友博士*2より分与されたものである. ラットへ の投与期間中は，室温に保存し，投与直前に開缶した. なお，開缶時のスズ濃度は $454 \pm 72.4 \mathrm{ppm}$ であった。

\section{2. 実験動物及び投与方法}

雄性, 21 日令, Jcl: Wistarラット（(株) 紀和実験動物 研究所より購入) を 3 群に分け, I 群 (34 匹) には対照 液 $(0.23 \%$ クエン酸に $15 \mathrm{ppm}$ の硝酸カリウムを加え， 水酸化ナトリウムを加えて $\mathrm{pH} 3.4$ にした溶液）を，II 群（30 匹）には缶溶出スズ原液を対照液で $1 / 2$ に希釈 した液（以後 $230 \mathrm{ppm}$ 缶スズ投与群と呼称）を, III 群 (33 匹) には午溶出スズ原液（以後 $454 \mathrm{ppm}$ 缶スズ投 与群と呼称）を各々飲料水として 4 週間自由摂取させ た. 飼料には(株)オリエンタル酵母製固型飼料 MF を 与光, 恒温恒湿（温度 $25 \pm 1^{\circ}$, 湿度 $50 \sim 60 \%$ ) の条件 で飼育し，毎週一回，体重測定を行った４ 4 週間後，ラ ットをエーテル麻酔下で開腹し, 腹大動脈より採血と殺 後, 血液学的検查を行い, 左右の大腿骨・上腕骨・脛骨 を摘出して, 強度試験及びスズ蓄積量の測定に供した。

\section{3. 骨強度試験方法}

骨の強度試験方法としての圧縮試験・曲げ試験は, イ ンストロン型材料試験機に, 南斎が各々の試験方法に応 じて，小動物用に開発した装置 ${ }^{10)}$ を接続して行った.

\section{(1) 骨試料の作製}

摘出した骨に付着する筋結合組織を取り除いた左右の 大腿骨と上腕骨, 及び右側の脛骨を試料とし, 乾燥を防

*1 厚生省スズの毒性研究班：昭和 $53 \sim 55$ 年度報告 書 p. $27 \sim 36$ (1981).

*2 現所属：大阪医療技術学園専門学校

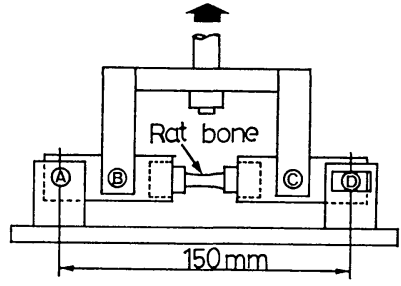

Fig. 1. Scheme of bending test apparatus $A, B, C$ and D: fulcrums

A bone was fixed between the fulcrums $\mathrm{B}$ and $\mathrm{C}$. The bending moment (M) was imposed on the bone by lifting the lever connected to the fulcrums $\mathrm{B}$ and $\mathrm{C}$ at a constant rate of $1.53 \mathrm{~mm} / \mathrm{min}$.

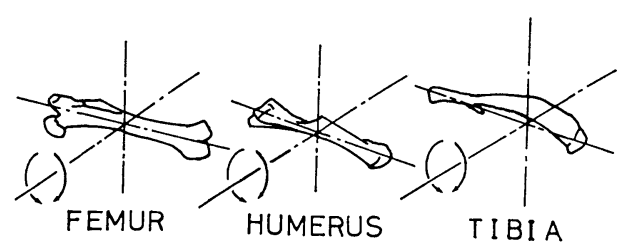

Fig. 2. Relation between the direction of the bending moment (M) and a long bone

Each pair of arrows shows the direction of the imposed bending moment.

いで御輿らの方法 ${ }^{10}$ に従って金属製金具に固定した.

(2) 曲げ試験

右側大腿骨・上腕骨・脛骨を試料とし，曲げ試験を行 った.

Fig. 1 は使用した曲げ試験装置の模式図で, 装置の支 点 $\mathrm{BC}$ 間に両端を金具で固定した試料骨を装着し, BC 部をインストロン型材料試験機により，移動速度 1.53 $\mathrm{mm} / \mathrm{min}$ で上向きに引張り，骨に曲げモーメント (M) を加觉た. Fig. 2 は骨と曲げモーメントの印加方向と の関係を示している.

$\mathrm{A}, \mathrm{B}, \mathrm{C}, \mathrm{D}$ の 4 点に支点のある 4 点支持法では, 骨 幹部に加わる曲げモーメントが BC 間では均一に分布す るため, 試料骨は骨幹部の最も脆弱な個所で破壊するこ とになる. 曲げ試験終了後, 破壊骨の骨髄を除き, 破壊 前の状態に復元した後, 破壊開始部位で骨長軸に対し垂 直に骨を切断し，その破断面の拡大写真を撮影した。

骨断面の模式図に対し，Fig. 3 に示したように曲げ モーメント M が加えられると，骨断面の重心 $\mathrm{G}$ を通る $\mathrm{X}-\mathrm{X}$ 軸の上側では引張応力, 下側では圧縮応力が生じ る. 破壊の際の塑性変形を無視すれば, 引張側の最大曲 げ応力 $\left(\sigma_{\mathrm{t} \text { max }}\right)$ 及び圧縮側での最大曲げ応力 $\left(\sigma_{\mathrm{c} \text { max }}\right)$ は 次式で求めることができる.

$$
\sigma_{\mathrm{t} \max }=\frac{\mathrm{M}}{\mathrm{I}} \mathrm{H}_{\mathrm{t}}
$$




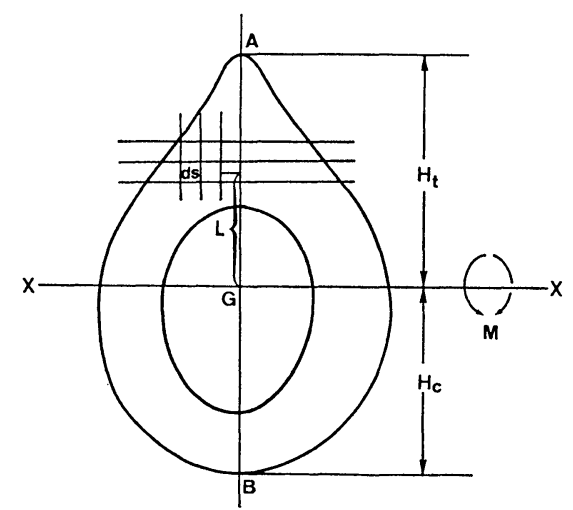

Fig. 3. Bone section and the secondary moment of inertia (I)

$$
\mathrm{I}=\int \mathrm{L}^{2} \mathrm{ds}
$$

$\mathrm{G}$ : center of gravity

$\mathrm{X}-\mathrm{X}$ : neutral axis

$$
\sigma_{\mathrm{cmax}}=\frac{\mathrm{M}}{\mathrm{I}} \mathrm{H}_{\mathrm{c}}
$$

ここに I は X-X 軸に関する断面二次モーメントで,

Fig. 3 中の式で定義される. $\mathrm{H}_{\mathrm{t}}$ は重心 $\mathrm{G}$ から引張側最 外層までの距離, $\mathrm{H}_{\mathrm{c}}$ は重心から圧縮側最外層までの距 離である. $\mathrm{I}, \mathrm{H}_{\mathrm{t}}, \mathrm{H}_{\mathrm{c}}$ は骨断面の拡大写真より生物パタ ーン解析装置 (LEITZ 社製 Bildanalyse System LEITZ-A·S・M) で測定した.

\section{(3) 王縮試験}

左側大腿骨・上腕骨を試料とし，圧縮試験に供した。 試料を金属性金具に固定し，骨の長軸方向に圧縮力が加 わるように, 引張り一圧縮変換器に装着した. この引張 り一圧縮変換器は, 曲げ試験と同一のインストロン型材 料試験機に接続されている. 骨の長軸方向に王縮速度 $0.5 \mathrm{~mm} / \mathrm{min}$ で圧縮力を加え, 各々の骨について骨端 部の圧縮破壊荷重 $F_{E}$, 骨幹部の圧縮破壊荷重 $F_{D}$ を求 めた。 圧縮試験方法及び強度の算出方法の詳細について は, 御輿らの方法 ${ }^{10)} に$ 準じた。破壊強度值は骨の大きさ
による影響を除くために単位断面積当りの 破壊荷重值 （破壊応力）として求めるべきであるが, 破壊断面の形状 が複雑で断面積の実測が困難であるので, 実測可能な骨 湿重量及び骨長を用いて骨の断面積次元量を求め, 応力 に相当する量を求めた. 本報ではこれらを, 骨湿重量に 基づく換算圧縮破壊応力と, 骨長に基づく換算圧縮破壊 応力と呼ぶことにし, 各々 $f(w)$ 及び $f(l)$ で表した.

$$
\begin{array}{r}
\mathrm{f}_{\mathrm{E}}(\mathrm{w})=\mathrm{k}_{1} \cdot \mathrm{F}_{\mathrm{E}} / \mathrm{w}^{2 / 3}, \quad \mathrm{f}_{\mathrm{D}}(\mathrm{w})=\mathrm{k}_{1} \cdot \mathrm{F}_{\mathrm{D}} / \mathrm{w}^{2 / 3} \\
\mathrm{f}_{\mathrm{E}}(\mathrm{l})=\mathrm{k}_{2} \cdot \mathrm{F}_{\mathrm{E}} / \mathrm{l}^{2}, \quad \mathrm{f}_{\mathrm{D}}(\mathrm{l})=\mathrm{k}_{2} \cdot \mathrm{F}_{\mathrm{D}} / \mathrm{l}^{2} \\
\left(\begin{array}{l}
\mathrm{k}_{1}, \mathrm{k}_{2} \text { は任意の定数 } \\
\text { こでは } \mathrm{k}_{1}=1, \mathrm{k}_{2}=1000 \text { とした }
\end{array}\right)
\end{array}
$$

\section{4. スズの定量}

缶溶出スズ濃度は, SATP 法 ${ }^{11)} に よ り$ 測定した.

骨中スズ蓄積量の定量は, 左側大腿骨を生理食塩水で 洗って骨髄を除いた後, $110^{\circ}$ で 24 時間乾燥させて重量 を測定し，その乾燥骨を硝酸を用いて無色透明になるま で湿式灰化した．灰化試料中のスズは，塚田らの方法 ${ }^{12)}$ を改変して, MIBK で抽出後, 水で逆抽出し, その 10 $\mu 1$ をフレームレス原子吸光分光光度計 (株) 島津製作所 製 AA-610S 及びグラファイトアトマイザー GFA-2 型 を用いて測定した.

\section{5. 血液学的検查}

赤血球数 $(\mathrm{RBC})$, 白血球数 (WBC), ヘモグロビン濃度 $(\mathrm{Hgb})$, ヘマトクリット值 (Hct) を Coulter Counter S (Coulter 社製) を用いて測定した. また血清鉄は Ferro Zine 法, アルカリホスファターゼ (ALP) 活性は Bessey Lowry 法で測定し, カルシウム濃度は 0 -cresolphthalein complexone (OCPC) 法, リン濃度はモリブ デン酸法を用いて測定した.

結果

\section{1.ラット体重・骨湿重量・骨長}

缶溶出スズ 4 週間投与後のラット体重, 大腿骨・上腕 骨・脛骨の湿重量及び骨の長さを Table 1 に示した. 対照群 (I 群) と缶スズ $454 \mathrm{ppm}$ 投与群 (III 群) 及び 缶スズ $230 \mathrm{ppm}$ 投与群 (II 群) との間には各測定項目

\begin{tabular}{|c|c|c|c|c|c|c|c|c|c|}
\hline \multirow[b]{2}{*}{ Dose } & \multirow[b]{2}{*}{ group } & \multirow[b]{2}{*}{$\mathrm{N}$} & \multirow{2}{*}{$\begin{array}{l}\text { Body } \\
\text { weight (g) }\end{array}$} & \multicolumn{2}{|c|}{ Femur } & \multicolumn{2}{|c|}{ Humerus } & \multicolumn{2}{|c|}{ Tibia } \\
\hline & & & & $\begin{array}{c}\text { Length } \\
(\mathrm{mm})\end{array}$ & $\begin{array}{c}\text { Wet } \\
\text { weight }(\mathrm{g})\end{array}$ & $\begin{array}{c}\text { Length } \\
(\mathrm{mm})\end{array}$ & $\begin{array}{c}\text { Wet } \\
\text { weight }(g)\end{array}$ & $\begin{array}{l}\text { Length } \\
(\mathrm{mm})\end{array}$ & $\begin{array}{c}\text { Wet } \\
\text { weight (g) }\end{array}$ \\
\hline I & Control & 27 & $205.5 \pm 21.6$ & $29.4 \pm 0.9$ & $0.57 \pm 0.06$ & $22.8 \pm 0.7$ & $0.28 \pm 0.03$ & $31.7 \pm 0.9$ & $0.38 \pm 0.04$ \\
\hline III & $230 \mathrm{ppm}$ & 27 & $208.9 \pm 20.7$ & $29.6 \pm 0.7$ & $0.58 \pm 0.05$ & $22.8 \pm 0.5$ & $0.28 \pm 0.02$ & $32.0 \pm 0.8$ & $0.38 \pm 0.04$ \\
\hline III & $454 \mathrm{ppm}$ & 28 & $201.3 \pm 23.2$ & $29.2 \pm 0.8$ & $0.56 \pm 0.05$ & $22.6 \pm 0.6$ & $0.27 \pm 0.02$ & $31.7 \pm 0.8$ & $0.37 \pm 0.03$ \\
\hline
\end{tabular}
とも有意な差は認められなかった. また，缶溶出スズ投 与によって期間中のラットの体重増加量にも各群間で差

Table 1. Body Weight, Bone Length and Wet Weight of Bone after 4 Weeks of Treatment $^{\text {a) }}$

$\mathrm{N}$ : Number of samples

a) Values represent the mean \pm S.D.

Significant difference was not observed among the groups. 


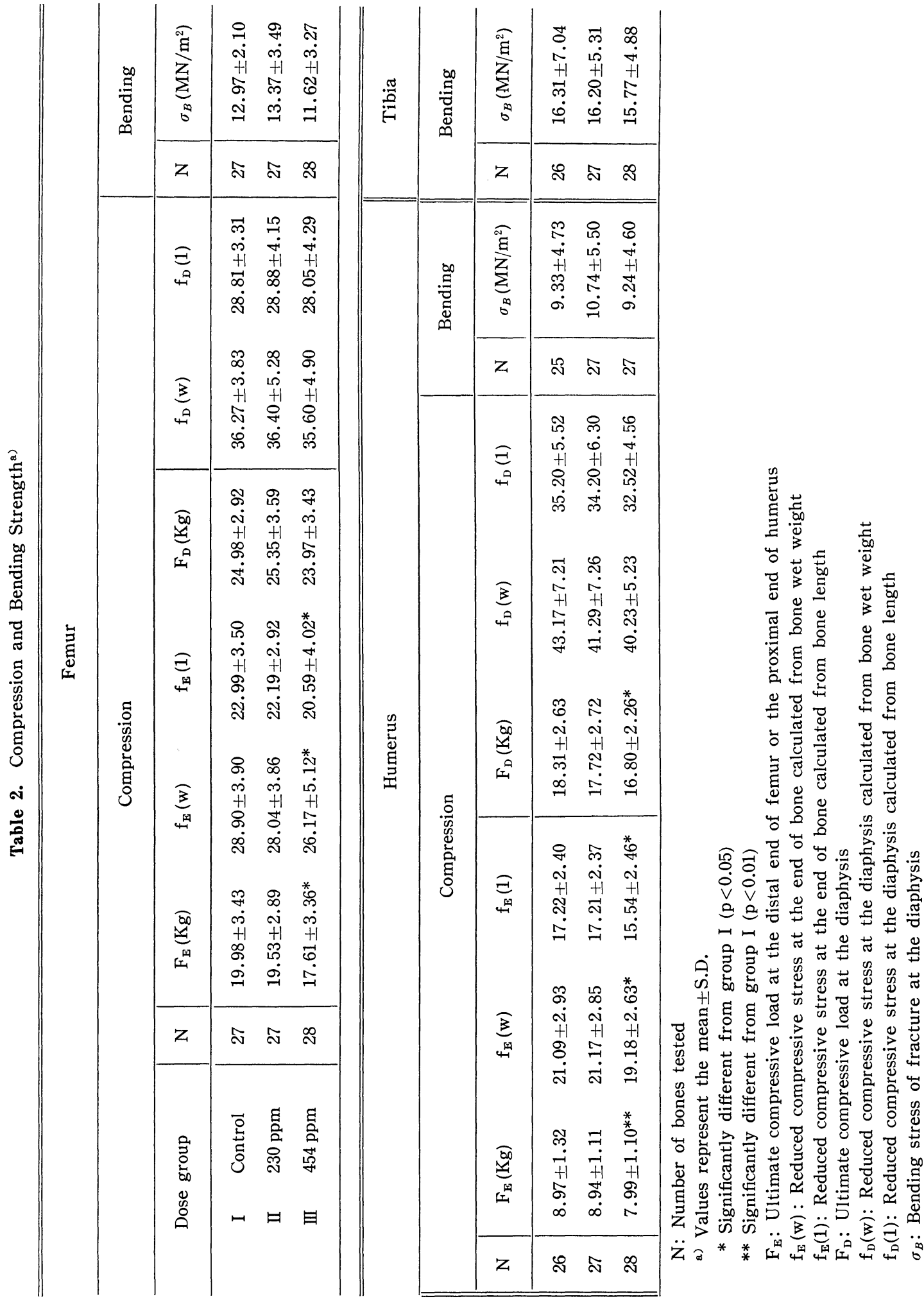


Table 3. Tin Concentration in Rat Femur ${ }^{a)}$

\begin{tabular}{cccc}
\hline \hline Dose group & $\mathrm{N}$ & $\begin{array}{c}\text { Tin content } \\
(\mu \mathrm{g} / \mathrm{g} \text { dry weight })\end{array}$ \\
\hline I & Control & 6 & $0.60 \pm 0.25$ \\
II & $230 \mathrm{ppm}$ & 6 & $8.61 \pm 1.42^{*}$ \\
III & $454 \mathrm{ppm}$ & 7 & $15.71 \pm 8.92^{*}$ \\
\hline
\end{tabular}

$\mathrm{N}$ : Number of femurs

a) Values represent the mean \pm S.D.

* Significantly different from group I $(\mathrm{p}<$ 0.01)

はなく，発育阻害は認められなかった。

\section{2. 圧縮及び曲げによる骨強度試験}

圧縮試験の場合，骨破壊はまず骨端部で生じ（大腿骨 では遠位骨端部，上腕骨では近位骨端部）さらに圧縮力 を加え続けることにより，遂には骨幹部が破壊した。

一方，曲げ試験による骨破壊は，大腿骨及び上腕骨 では引張側で，脛骨では圧縮側で開始する，従って，大 腿骨及び上腕骨では引張側の最大曲げ応力を破壊応力 $\left(\sigma_{\mathrm{B}}\right)$ とし, 脛骨では圧縮側の最大曲げ応力を破壊応力と した. Table 2 に大腿骨・上腕骨の骨端及び骨幹部の圧 縮破壊荷重值，換算圧縮破壊応力，曲げ破壊応力を，ま た脛骨の曲げ破壊応力を示した.

$230 \mathrm{ppm}$ 缶スズ投与群を対照群と比較すると, 压縮試 験, 曲げ試験, いずれの結果からも骨強度の有意な低下 は認められなかった。しかし $454 \mathrm{ppm}$ 缶スズ投与群に ついては対照群と比較すると, 圧縮試験では, 大腿骨, 上腕骨ともに骨端部の圧縮破壊荷重 $F_{E}$, 骨湿重量に基 づく換算圧縮破壊応力 $\mathrm{f}_{E}(\mathrm{w})$, 骨長に基づく換算圧縮破 壊応力 $\mathrm{f}_{\mathrm{E}}(\mathrm{l})$ のいずれにおいても有意な低下が認められ たししかし骨幹部については，大腿骨の場合，圧縮力に 対する強度低下は認められなかった，上腕骨の場合で も，骨幹部の圧縮強度については， $\mathrm{F}_{\mathrm{D}}$ は有意水準 $5 \%$ で低下が認められたが， $f_{D}(w), f_{D}(1)$ では，有意な低下 は認められなかった。
曲げ試験に打いては, $230 \mathrm{ppm}$ 缶スズ投与群及び 454 $\mathrm{ppm}$ 缶スズ投与群のいずれにも曲げ破壊応力に有意な 変化は認められなかった。

\section{3. 骨中スズの測定}

Table 3 に示すように，スズの投与量に応じて骨への スズの蓄積量が增加した.

\section{4. 血液学的所見}

Table 4 に示すように, $454 \mathrm{ppm}$ 缶スズ投与群は対照 群と比べてへモグロビン濃度, ヘマトクリット值, $\mathrm{MCV}, \mathrm{MCH}$ に有意な低下が認められたが，230 ppm 缶スズ投与群には，これらの変化は認められなかった。 血清アルカリホスファターゼ活性, 鉄, カルシウム, リ ン濃度には, $230 \mathrm{ppm}$ 缶スズ投与群, $450 \mathrm{ppm}$ 缶スズ 投与群ともに，対照群との間に有意な差は認められなか った.

\section{考察}

スズの毒性に関する動物実験の中でも，日常食品とし て摂取される缶詰食品や，ジュース缶からの溶出スズに ついての毒性実験は，食品衛生学上重要である.

今回著者らは，モデルジュース缶より溶出したスズ $454 \mathrm{ppm}$ を 3 週令のラットに 4 週間摂取させた結果, 骨 強度の低下及び低色素性小球性貧血を認めている，缶溶 出スズによる貧血は，Groot ${ }^{13)}$ らの塩化第一スズ投与実 験で観察された結果と一致し，缶溶出スズも造血系に何 らかの影響を与えることが示唆される．また，強度試験 においては，大腿骨遠位骨端部及び上腕骨近位骨端部に おいて強度低下が認められた。 今回用いた 2 つの強度試 験方法のうち，圧縮試験は骨端部，骨幹部の強度を測定 する方法であり，曲げ試験は骨幹部のみの強度を測定す る方法である．骨幹部の強度測定が可能な両試験方法の 間には，負荷応力の分布を考慮すると次のような相違点 がある，すなわち，圧縮試験では骨の長軸方向に偏りな く圧縮力が加えられ，骨断面全体に均一に力が加わるた めに，骨幹部の平均的な強度を測定しているのに対し， 曲げ試験では，破壊が開始する骨皮質部の強度を求めて いるといら点である．従って，今回得られた結果から

Table 4. Blood Test of Rat Administered Corrosion Tin ${ }^{a)}$

\begin{tabular}{|c|c|c|c|c|c|c|c|}
\hline Dose group & $\mathrm{N}$ & $\begin{array}{c}\text { WBC } \\
\left(\times 10^{3} / \mathrm{mm}^{3}\right)\end{array}$ & $\begin{array}{c}\mathrm{RBC} \\
\left(\times 10^{8} / \mathrm{mm}^{3}\right)\end{array}$ & $\mathrm{Hgb}(\mathrm{g} / \mathrm{dl})$ & $\operatorname{Hct}(\%)$ & $\operatorname{MCV}\left(\mu^{3}\right)$ & $\mathrm{MCHC}(\%)$ \\
\hline Control & 34 & $9.0 \pm 2.8$ & $6.2 \pm 0.4$ & $13.3 \pm 1.1$ & $36.9 \pm 2.6$ & $59.7 \pm 2.5$ & $21.5 \pm 0.9$ \\
\hline $230 \mathrm{ppm}$ & 30 & $8.6 \pm 3.0$ & $6.1 \pm 0.6$ & $13.2 \pm 1.0$ & $36.1 \pm 2.7$ & $59.1 \pm 2.0$ & $21.5 \pm 0.9 \quad 36.1 \pm 0.8$ \\
\hline $454 \mathrm{ppm}$ & 33 & $7.8 \pm 1.8$ & $6.0 \pm 0.6$ & $12.6 \pm 1.3^{*}$ & $34.7 \pm 3.3^{* *}$ & $57.8 \pm 2.7 * *$ & $20.9 \pm 1.0^{* *} 35.8 \pm 1.0$ \\
\hline
\end{tabular}

$\mathrm{N}$ : Number of animals

WBC: White blood cells RBC: Red blood cells

Hbg: Hemoglobin

Hct: Hematocrit MCV: Mean corpuscular volume

$\mathrm{MCH}$ : Mean corpuscular hemoglobin MCHC: Mean corpuscular hemoglobin concentration

a) Values represent the mean \pm S.D.

* Significantly different from group I $(\mathrm{p}<0.02)$

** Significantly different from group I $(p<0.01)$ 
は, 骨幹部においては, 負荷応力の分布の違う 2 つの骨 強度試験方法によっても，いずれの投与群にも明確な骨 強度変化は認められなかった，ところが，骨端部では， 缶溶出スズ投与による骨強度への影響が強く現われてい る. 著者らの塩化第一スズ投与ラットでの圧縮試験で も, 今回の缶溶出スズ投与実験と同様, 骨端部の圧縮強 度が低下し, 骨幹部の強度は低下しないといら結果が得 られている. また, 山口ら ${ }^{14)} は$, 塩化第一スズをラット に投与し大腿骨骨端部と骨幹部のカルシウム量の変化を 調べ，骨幹部よりも骨端部に打いて低下が著しいことを 報告している.これらの事実に加えて，今回の実験では 成長期の幼若ラットを用いたことを考慮すると，スズは 成長の著しい骨端部位に作用し, 骨の石灰化, 骨梁の形 成などに影響を及ぼし，強度の低下を炭きおこすと考え られる。

山ロら ${ }^{9)}$ は，ラットを用いての塩化第一スズ及び缶溶 出スズ投与実験において，骨には特異的にスズが蓄積さ れること, 及び, 生化学的変化も骨において著しいこと を示している。 また，Hamilton ら ${ }^{6)}$ は，健康なイギリ ス住民の死体骨中のスズ蓄積量は $4.1 \mu \mathrm{g} / \mathrm{g}$ ash である ことを報告している，普通，乾燥骨を灰にすると重量は 2/3 になるので，この值を dry weight 当りに換算する と, $2.7 \mu \mathrm{g} / \mathrm{g}$ dry weight となる. Schroeder らによ れば, 病院食において缶詰食品利用回数が増えると, 七 トのスズ摂取量は 3〜30 倍に増加すること，また缶詰食 品を多食するアメリカ住民はアフリカ住民と比べてスズ の藏器蓄積量が 6〜8 倍高いことが忍められている. 従 って, 日常食品からのスズの摂取量が増加した場合, ヒ トの骨中スズ蓄積量は骨強度低下の認められた 454 $\mathrm{ppm}$ 缶スズ投与群の蓄積量 $15.7 \mu \mathrm{g} / \mathrm{g}$ dry weight に 近い值となることが予想され，特に成長期のヒトの骨に 影響の現われる可能性が考えられる。これまで, 骨に対 するスズ毒性についての報告は少ないので今後速やかな 解明が必要である.

稿を終るに当り，本研究のために，モデルジュースを
御提供下さった大阪医療技術学園専門学校 堀尾嘉友博 士, 御指導と御鞭撻を賜わった奈良県立医大公衆衛生学 教室 土肥祥子博士, 並びに奈良県衛生研究所 青木善 也博士の各位に心から感謝の意を表します。

文献

1) Schroeder, H. A., Balassa, J. J., Tipton, I. H.: J. Chron. Dis. 17, 483 502 (1964).

2) Hadžimicev, P.: Khranit. Prom. 20, 18 20 (1971).

3) Catala, R., Royo, I. J., Prino, E.: Rev. Agroquim. Tecnol. Aliment. 11, 409 417 (1971).

4) Benoy, J. C., Hopper, P. A., Schneider, R.: Fd Cosmet. Toxicol. 9, 645 656 (1971).

5) Barker, W.H., Runte, V.: Am. J. Epidemiol. 96, 219 226 (1972).

6) Hamilton, E. I., Minski, M. J., Cleary, J. J.: Sci. Total Environ. 1, 341 374 (1972/1973).

7）和田昭治, 青木善也, 林 秀茂, 森山忠重：骨代 謝 12，428４33 (1979).

8) Ogoshi, K., Kurumatani N., Aoki, Y., Moriyama, T., Nanzai, Y.: Toxicol. Appl. Pharmacol. 58, 331 332 (1981).

9) 山口正義, 岡田昌二: 衛生化学, 25 (5), 256 261 (1979).

10）御與久美子, 青木善也, 車谷典男, 森山忠重, 南 斎征夫：日衛誌. 36 (3)，584～595 (1981).

11）日本薬学会編：“衛生試験法・注解” p. 310 311 (1973).

12) 塚田司郎, 出村礼子, 山本郁男：食衛誌. $22(4)$, 307 311 (1981).

13) Groot, A. P., Feron, V. J., Til, H. P.: Fd Cosmet. Toxicol. 11, 19 30 (1973).

14) Yamaguchi, M., Okada, S.: Toxicology Letters 6, 177 180 (1980). 